\title{
SENTINEL-2 FOR HIGH RESOLUTION MAPPING OF SLOPE-BASED VEGETATION INDICES USING MACHINE LEARNING BY SAGA GIS
}

Polina LEMENKOVA*

* Russian Academy of Sciences, Schmidt Institute of Physics of the Earth, Laboratory of Regional Geophysics and Natural Disasters, Bolshaya Gruzinskaya Street, 303, 10, 1, Moscow, Russian Federation, RU-123995, pauline.lemenkova@gmail.com

DOI: 10.2478/trser-2020-0015

KEYWORDS: Sentinel-2, SAGA GIS, Cameroon, remote sensing, vegetation.

\section{ABSTRACT}

Vegetation of Cameroon includes a variety of landscape types with high biodiversity. Ecological monitoring of Yaoundé requires visualization of vegetation types in context of climate change. Vegetation Indices (VIs) derived from Sentinel-2 multispectral satellite image were analyzed in SAGA GIS to separate wetland biomes, as well as savannah and tropical rainforests. The methodology includes computing 6 VIs: NDVI, DVI, SAVI, RVI, TTVI, CTVI. The VIs shown correlation of data with vegetation distribution rising from wetlands, grassland, savanna, and shrub land towards tropical rainforests, increasing values along with canopy greenness, while also being inversely proportional to soils, urban spaces and Sanaga River. The study contributed to the environmental studies of Cameroon and demonstration of the satellite image processing.

ZUSAMMENFASSUNG: Sentinel-2 zur Kartierung von Neigung bedingten Vegetationsindizes mithilfe von maschinellem Lernen von SAGA GIS.

Die Vegetation von Kameruns umfaßt eine Vielzahl verschiedener Landschaftstypen. Das Ökologische Monitoring von Yaoundé erfordert die Visualisierung der Vegetationstypen im Kontext des Klimawandels. In diesem Artikel wird die Erfahrung mit SAGA GIS vorgestellt, einem Hilfsmittel zur Satellitenbildverarbeitung. Die Arbeit analysiert die Vegetationsverteilung in Yaoundé anhand von sechs Vegetationsindizes (VIs) und einem hochauflösenden multispektralen Sentinel-2-Satellitenbild. Die Methodik umfasst eine Verarbeitung des Sentinel-2 zur Berechnung der VIs unter Verwendung verschiedener Algorithmen: NDVI, DVI, SAVI, RVI, TTVI, CTVI. Die grafische Darstellung der Häufigkeitsverteilung der Daten wird mittels eines Histogramms angezeigt. Die VIs zeigten eine Korrelation der Daten mit der Vegetationsverteilung, die von Feuchtgebieten, Grünland, Savanne und Gebüschen bis zu den tropischen Regenwäldern ansteigt und damit sich auch die grüne Saumdichte erhöht Der Anstieg ist umgekehrt proportional zu den Böden, städtischen Räumen und Sanaga Fluss. Die Satellitenbildverarbeitung in der Kartographie ist eine Frage von großer Aktualität und Bedeutung. Die Arbeit leistet einen Beitrag zu den Umweltstudien in Kamerun.

REZUMAT: Sentinel-2 pentru cartografierea indicilor de vegetație bazați pe înclinarea pantelor folosind învăţarea automată de la SAGA GIS.

Vegetația din Camerun include o varietate de tipuri de peisaje cu biodiversitate ridicată. Monitorizarea ecologică a orașului Yaoundé necesită vizualizarea tipurilor de vegetaţie în contextul schimbărilor climatice. Indicii de vegetaţie (VI) derivați din imaginea de satelit multispectrală Sentinel-2 au fost analizați în SAGA GIS pentru a separa biomurile zonelor umede, savana și pădurile tropicale tropicale. Metodologia include calculul a 6 VI: NDVI, DVI, SAVI, RVI, TTVI, CTVI. VI au arătat corelaţia datelor cu distribuţia vegetaţiei care crește din zonele umede, pajiști, savane și arbuști spre pădurile tropicale, creșterea valorilor împreună cu verdele vegetaţiei și invers proporțională cu solurile, spaţiile urbane și râul Sanaga. Studiul a contribuit la studiile de mediu ale Camerunului. 


\section{INTRODUCTION}

Wetlands are unique habitats that have become critically reduced in many areas, even becoming extinct in some places which raise the question of their protecting and conservation of their biodiversity (Brock and van Vierssen, 1992; Beatty et al., 2014; Schneider-Binder, 2020). This is caused by the perception that they have a lower value compared to the forests, and can be converted for more productive land use types (Bosma et al., 2017; Nawarathne et al., 2020). However, besides the environmental values, wetlands are highly important habitat for medical plants. For example, Fonkou et al. (2017) made a survey of wetland medicinal plants in the Western Highlands of Cameroon and documented that wetlands here are rich in medicinal macrophyte species, used as food and products for traditional health care. In total, 82 wetland macrophytes of medicinal importance, 64 genera and 40 families were documented to treat over 74 different ailments in Cameroon.

Nevertheless, wetland biodiversity recently became endangered in Cameroon (Wanzie, 2003). The destruction of the wetlands has resulted in a reduction in biodiversity and the endangerment of species that exists in wetland habitats (Price et al., 1992; Amenu and Mamo, 2018; Asomani-Boateng, 2019). Endangered wetlands can lead to social and economic drawbacks for local population who use medical plants growing in wetlands for their life maintenance. Deterioration of such precious landscapes would damage the tropical ecosystems of Cameroon. In view of this, the presented research demonstrated a technical approach of vegetation mapping using advanced cartographic methods of SAGA GIS. In response to the need of the environmental monitoring, this paper contributes to the methodological presentation of wetland conservation by introducing cartographic processing and visualization of the remote sensing data by SAGA GIS for environmental monitoring and detection of vegetation in Cameroon.

Satellite remote sensing applied in ecological studies enables to perform an advanced vegetation analysis, because high-resolution data is continuously provided by the space industry and placed in the open access data pool (e.g. GloVis), and can be used freely for thematic environmental mapping. The remote sensing data, such as Sentinel-2 or Landsat TM, creates advances in computational cartography allowing measuring VIs, capture land cover types variability, and map biodiversity patterns in various regions of the Earth. Among others, a progress in the machine-learning approaches in cartographic data visualization and interpretation includes new developed algorithms that measure VIs, as shown in this paper: NDVI, DVI, RVI, TTVI, CTVI, SAVI. Using publicly available large datasets from NOAA in combination with the GIS software, enables to model VIs of multiple species distributions at various scales (Gao, 1996; Jurgens, 1997; Xu, 2006; Lemenkova, 2014, 2015b).

Monitoring tropical wetlands is increasingly apparent in the face of climate and environmental change in Africa. Wetlands are distributed in various types of landscapes, such as coastal areas, mangroves, lakes, seasonally flooded meadows, sedge marshes, shrub or open bogs, swamps, fens, flood-plains, to mention a few. The costal lowlands of Cameroon are notable for a swampy environment of the humid tropical coasts. Extensive wetlands of Cameroon include mouths of coastal rivers along the humid tropical coastlines, costal lowlands from the Limbe area to the west, and the Douala area to the east; which today is characterized by a lagoon system (Asangwe, 2009). Simultaneously, the Cameroon recently is experiencing rapid urbanization which results in the extensive spatial expansion in the wetland areas. 


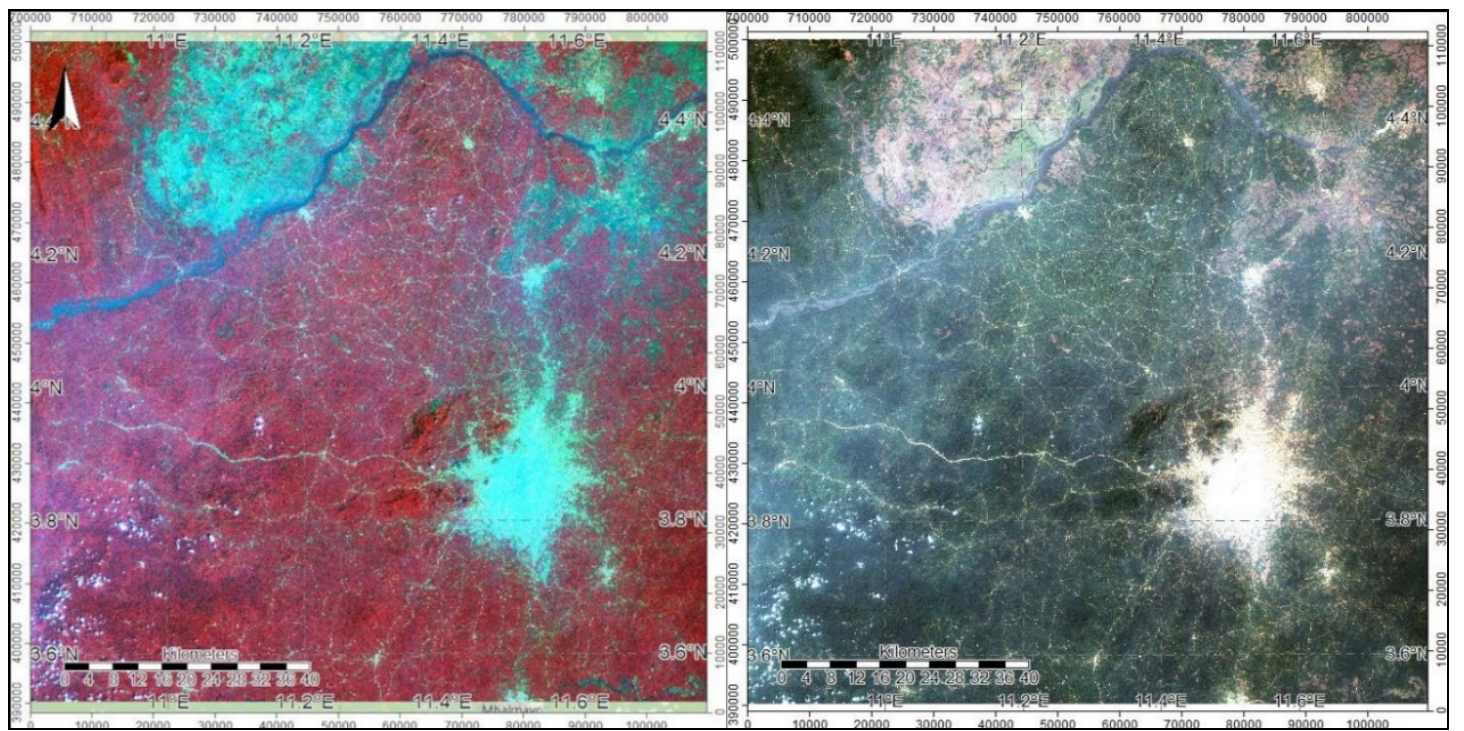

Figure 1: Sentinel-2 band composites: 8-4-2 (colour infrared, false colour composite), left, bands 4, 3, 2, natural colour composite, right; mapping: SAGA GIS.

As a consequence, wetlands areas diminished compared to the urban spaces which resulted in changes in vegetation distribution and land cover types (Asangwe, 2006). The territory of Cameroon is experiencing significant land use changes caused by the land restructuring, intensification of agricultural activities and urbanization since 1990, varying in dynamics of the vegetation cover change and strength of anthropogenic activities in different regions of the country. For instance, a forest decline was detected in recent thirty years, the decrease of dense forest. Other types of landscapes experienced degradation by the anthropogenic impacts. For instance, these include the industrial emissions or increased domestic waste water discharge in the urban areas. The need for environmental mapping naturally evolved interest in GIS methods of spatial analysis of the vegetation distribution including wetland zones. In response to the need of the environmental monitoring of Cameroon, the research presents the functionality of SAGA GIS for remote sensing image processing which can be used to map various vegetation types including wetlands. The SAGA GIS enables accurate cartographic visualization of vegetation types by machine learning approach using high-resolution multispectral Sentinel-2 imagery (10 m) taken in 2020.

Land cover in Cameroon includes various types of vegetation and features of the land coverage, such as forest, equatorial ever green humid forests, savannas or grasslands, wetlands and bare lands. Due to the changed types of land use, the proportions of the natural vegetation and urban spaces are changing. The examples of the new land use types include development of the plantations (palm plantation), the forestry development, the harbour activities in the coastal areas of Cameroon and the effects of industrialization. After the land use changes, the biodiversity should be restored on land that has previously been heavily cultivated or abandoned, which takes time and additional processes on land re-cultivation, e.g. introducing restoration projects. The maintenance and monitoring of biodiversity within unchanged seminatural landscapes contributes to the processes of the sustainable development of Cameroon. Vegetation Indices (VIs), as a combination of values in spectral bands of the satellite images can be used to highlight vegetation distribution in ecological studies. Specifically, the VIs are 
helpful in assessment of vegetation greenness and health, which is applicable in agricultural monitoring. VIs are a numerical computation of various bands with the most often used are red (R) and near infra-red (NIR) spectral bands, or a transformation of other VIs. The VIs are aimed to enhance the visibility of vegetation on a satellite image. The visualization of the VIs allows to perform spatial and temporal comparison of the photosynthetic properties of vegetation and canopy structure (Bannari et al., 1995). As a calculation of spectral bands, the VIs are calculated without any assumptions regarding land cover types, vegetation type, or climate settings using machine classification of the spectral reflectance. The VIs is useful in monitoring seasonal, quarterly, annual, or even long-term variations of canopy using a satellite scene. An analysis of the long-term variations is possible using the time-series analysis based on a set of several scenes.

The Vis are used for assessment of the environmental variables such as biophysical characteristics of plants, chlorophyll and pigment content, vegetation health or dry biomass, moisture content, phenological, biophysical characteristics of plants, structure of leaves, soil moisture, and plant temperature (Campbell, 2002). There is a number of VIs developed using various algorithms starting from a very simple Difference Vegetation Index (DVI) that only shows the difference between the R and NIR, to a very complex band combination, such as Thiam's Transformed Vegetation Index (Thiam, 1997) or Corrected Transformed Ratio Vegetation Index (Perry and Lautenschlager, 1984). Among all VIs, the most well-known is, by far, a Normalized Difference Vegetation Index (NDVI), which is also used in this study.

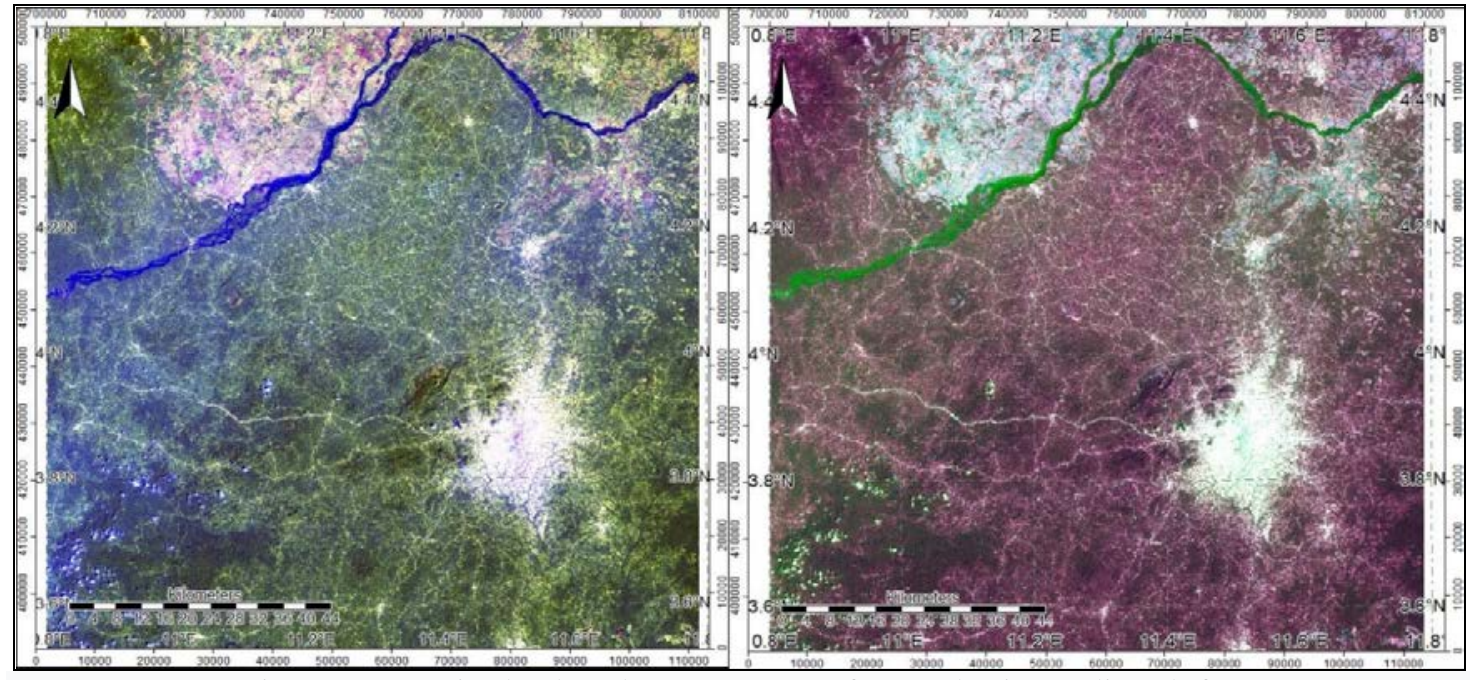

Figure 2: Sentinel-2 bands (B12-11-2), for geologic studies (left).

Sentinel-2 bands B11, B4, B12 for water detection (right).

With the increasing availability of remote sensing data at high temporal and spatial resolutions, such as Sentinel-2 with $10 \mathrm{~m}$. (Fig. 1), there is a possibility of the effective processing of the imagery for the calculation of VIs. Alongside the increase in data variety (Landsat TM, Sentinel-2, MODIS), the resources to visualize images, compute, and plot VIs have boost. In response to such a need, the SAGA GIS (System for Automated Geoscientific Analyses), have proposed several VIs that can be applied for satellite data processing for vegetation mapping. SAGA GIS, an open source advanced GIS for raster analysis, has been developed by the Department of Physical Geography, University of Göttingen, Germany, and is a powerful tool for processing of the spatial data (Böhner et al., 2006). 
The principle of the VIs calculation is based on the fact that vegetation is spectrally distinct from other land cover types, such as soils, urban areas, minerals and water (Lemenkova, 2011), due to its reflectance in individual wavelength regions (a.k.a. bands). The difference between near infra-red (NIR) reflectance and red (R) reflectance for soil is much less than that for the healthy green vegetation. This fact is widely used for the VIs calculations that enable it to detect regions with healthy green vegetation (forest, dense canopy trees, agricultural crop fields with green plants). Such areas can be clearly detected and distinct from other land cover types, especially urban city spaces, roads, water bodies, and so on. There are a variety of various VIs based on different approaches in mathematical algorithms. However, all of them are based on the fundamental accentuating the difference between $\mathrm{R}$ and NIR reflectance in image pixels with a focus on vegetation areas.

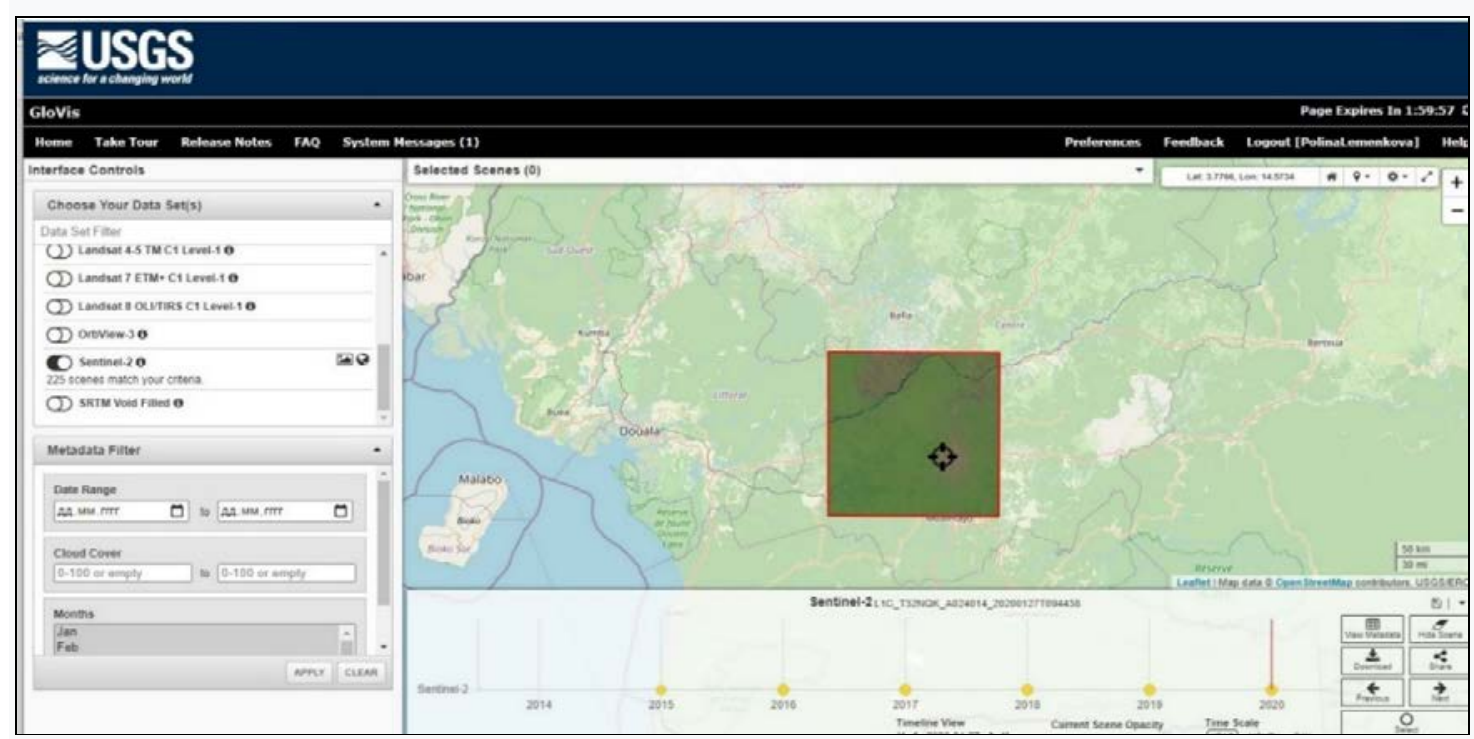

Figure 3: Data capture using the GloVis interface.

Six VIs were used with the following abbreviations: 1) NDVI - Normalized Difference Vegetation Index; 2) DVI - Difference Vegetation Index; 3) SAVI - Soil Adjusted Vegetation Index; 4) RVI - Ratio Vegetation Index; 5) TVI - Transformed Vegetation Index; 6) CTVI - Corrected Transformed Vegetation Index. Probably the most well-known is the NDVI NDVI $=(\mathrm{NIR}-\mathrm{R}) /(\mathrm{NIR}+\mathrm{R})$, while the simplest VI is the DVI $(\mathrm{DVI}=\mathrm{NIR}-\mathrm{R})$. Various VIs have advantages and drawbacks, they are better suited to a variety of parameters (Crippen, 1990). For example, the DVI is more sensitive to the amount of vegetation and well distinguishes between soil and vegetation, however, it does not deal with the difference between reflectance and radiance caused by the atmosphere or shadows. We compared all the eight VIs applied for a Sentinel-2 image and to demonstrate the behaviour of the vegetation visualized on these VIs.

The study area includes the selected region of Yaoundé, Cameroon (Fig. 2), which includes various land cover types, such as wetlands, savannas, urban, rainforests, mixed forests, and agricultural regions. Some lands are affected by external factors such as climate change (Fokeng and Meli, 2015; Fokeng et al., 2020). This resulted in the development of biodiversity conservation program for the protected areas (Lambi et al., 2012). These include, for instance, Bafut-Ngemba Forest Reserve, according to the Convention on Biological 
Diversity (Ministry of Environment and Forestry, 1994; Ministry of the Environment and Protection of Nature, 2009) and programs on forest management (Muam, 1999). Takem-Mbi (2013) showed an increase of deforestation along with farmland increased between 1978 and 2006 in Cameroon, supported by studies of Seiny-Boukar et al. (1992) on savannahs.

The climate impact factor can further be illustrated by deforestation, which has greatly increased in reserve areas of Cameroon due to the climate change and food crop plantations cultivated in villages. At the same time, ecological variables may reflect a complex impact from climate change. For instance, distribution of soil organic carbon is consistent with the agro-ecological and environmental patterns (Silatsa et al., 2020), or various land cover types along with the climate change reflecting soil quality in Cameroon (Ngo-Mbogba et al., 2015; Tsozue et al., 2015). These examples highly illustrate the actuality of the remote sensing data visualization using GIS for sustainable land management and analysis of climate change, improving the monitoring of vegetation health in Cameroon and ecological monitoring.

\section{MATERIAL AND METHODS}

The data include Sentinel-2 image covering the region of Cameroon, Yaoundé, and Central Africa. The metadata on the used image is presented in table 1. Data strip ID S2A_OPER_ MSI_L1C_DS_EPAE_20200127T104504_S20200127T094438_N02.08. The image is projected in UTM cartographic projection zone 32N, Datum WGS84, units in meters. Platform Sentinel-2A by ESA Agency. Acquisition: 2020-01-27T09:44:38.407Z and 2020-0127T09:51:40.517Z. Entity ID is L1C_T32NQK_A024014_20200127T094438. Image resolution is $10,20,60 \mathrm{~m}$, differing in various spectral bands. Tile number is T32NQK, archiving center: Environmental Protection Agency (EPA). The geodetic specifications include Sun Zenith Angle Mean (33.0302446510534 ${ }^{\circ}$ ) and Sun Azimuth Angle Mean $\left(133.8734719268990^{\circ}\right)$. Data take type value: INS-NOBS (Nominal Observation). The product format is JPEG2000, zero cloudiness. The data were captured in GloVis repository (Fig. 3).

Table 1: Metadata specifications of the Sentinel-2 image.

\begin{tabular}{|c|c|c|c|c|c|}
\hline EPSG Code & 32632 & Quantif. & 10000 & Center Latitude & $4^{\circ} 01^{\prime} 26.45 ” \mathrm{~N}$ \\
\hline Center lon dec & 11.2953727 & Vendor & EPAE & Center Longitude & 11'17’43.34”E \\
\hline Cloud Cover & 0.00000 & $\begin{array}{l}\text { Vendor } \\
\text { Tile ID }\end{array}$ & $\begin{array}{l}\text { L1C_T32NQ_A } \\
\text { 024014_202001 } \\
\text { 27T094438 } \\
\end{array}$ & NW Lat & $4^{\circ} 31^{\prime} 18.05^{\prime \prime} \mathrm{N}$ \\
\hline $\begin{array}{l}\text { Orbit } \\
\text { Direction }\end{array}$ & $\begin{array}{l}\text { Descending } \\
\text { Orbit }\end{array}$ & $\begin{array}{l}\text { Orbit } \\
\text { Number }\end{array}$ & 136 & NW Long & 1048’08.16” E \\
\hline $\begin{array}{l}\text { Production } \\
\text { Date }\end{array}$ & $\begin{array}{l}\text { 2020-01- } \\
\text { 27T10:45:04. } \\
\text { 000000Z }\end{array}$ & $\begin{array}{l}\text { NE Corner } \\
\text { Lat dec }\end{array}$ & 4.5185436 & NE Lat & $4^{\circ} 31^{\prime} 06.76^{\prime \prime} \mathrm{N}$ \\
\hline $\begin{array}{l}\text { Datatake } \\
\text { Identifier }\end{array}$ & $\begin{array}{l}\text { GS2A_20200 } \\
\text { 127T093241_- } \\
024014 \_N 02 . \\
08\end{array}$ & $\begin{array}{l}\text { NW Long } \\
\text { dec }\end{array}$ & 10.8022674 & NE Long & 11²4’28.53”E \\
\hline Data Type & UINT16 & & & SE Lat & $3^{\circ} 31^{\prime} 34.98 ” \mathrm{~N}$ \\
\hline Product Type & S2MSI1C & $\begin{array}{l}\text { NW Lat } \\
\text { dec }\end{array}$ & 4.5216809 & SE Long & 11²4’16.37’E \\
\hline $\begin{array}{l}\text { Processing } \\
\text { Level }\end{array}$ & LEVEL-1C & $\begin{array}{l}\text { SW Lat } \\
\text { dec }\end{array}$ & 3.5288293 & SW Lat & $3^{\circ} 31^{\prime} 43.78^{\prime \prime} \mathrm{N}$ \\
\hline NE Long dec & 11.7912577 & SE Lat dec & 3.5263828 & SW Long & 10॰48’00.31’Е \\
\hline SW Long dec & 10.8000849 & $\begin{array}{l}\text { SE Long } \\
\text { dec }\end{array}$ & 11.7878806 & Center Lat dec & 4.0240124 \\
\hline
\end{tabular}


Table 2: Algorithms of the calculation of VIs based on SAGA GIS; NIR = near infrared, $\mathrm{R}=$ red, $\mathrm{S}$ = soil adjustment factor.

\begin{tabular}{|c|l|l|}
\hline 1. & Difference Vegetation Index & $\mathrm{DVI}=\mathrm{NIR}-\mathrm{R}$ \\
\hline 2. & NormalizedDifferenceVegetationIndex(Rouseetal.1974) & $\mathrm{NDVI}=(\mathrm{NIR}-\mathrm{R}) /(\mathrm{NIR}+\mathrm{R})$ \\
\hline 3. & Ratio Vegetation Index (Richardson and Wiegand, 1977) & $\mathrm{RVI}=\mathrm{R} / \mathrm{NIR}$ \\
\hline 4. & Transformed Vegetation Index (Deering et al., 1975) & $\mathrm{TVI}=[(\mathrm{NIR}-\mathrm{R}) /(\mathrm{NIR}+\mathrm{R})+0.5]^{\wedge}$ \\
& & 0.5 \\
\hline 5. & Corrected Transformed Ratio Vegetation Index & $\mathrm{CTVI}=[(\mathrm{NDVI}+0.5) / \mathrm{abs}(\mathrm{NDVI}+$ \\
& (Perry and Lautenschlager, 1984) & $0.5){ }^{*}[\mathrm{abs}(\mathrm{NDVI}+0.5)]^{\wedge} 0.5$ \\
\hline 7. & Thiam's Transformed Vegetation Index (Thiam, 1997) & $\mathrm{RVI}=[\mathrm{abs}(\mathrm{NDVI})+0.5]^{\wedge} 0.5$ \\
\hline 6. & Soil Adjusted Vegetation Index (Huete, 1988) & $\mathrm{SAVI}=[(\mathrm{NIR}-\mathrm{R}) /(\mathrm{NIR}+\mathrm{R})]^{*}(1+\mathrm{S})$ \\
\hline
\end{tabular}

The reason for choosing Sentinel image consists in its following advantages. In contrast to other satellite data also used in agricultural monitoring, such as MODIS (Fritz et al., 2015; Testa et al., 2018) and Landsat-TM (Shang and Zhu, 2019), Sentinel has a higher spatial resolution: 10 to $20 \mathrm{~m}$ against $30 \mathrm{~m}$ by the Landsat TM (Claverie et al., 2018) and two satellites for synthetic aperture radar (SAR) in a Sentinel-1 and the optical sensor in a Sentinel2. Besides, Sentinel-2 satellite has more spectral channels from the R bands compared to the Landsat-8. High-resolution Sentinel satellite images are a free and open source, which resulted from the Copernicus Program developing and being operated by European Space Agency (ESA) for an Earth observation technology.

The Sentinel-2 enables monitoring on vegetation ecosystem dynamics and functioning through the optical imagery at a fine spatial resolution (10-60 m) systematically acquired over terrestrial areas with a $290 \mathrm{~km}$ field of view (Nowakowski, 2015). The Sentinel-2 supports a broad range of cartographic applications such as vegetation mapping, land cover change detection, agricultural monitoring, raster data classification, and ecological mapping (Hagolle et al., 2018). The launch of the first satellite, Sentinel-2A, was in 2015. The Sentinel-2 is a multi-spectral data width 13 bands in the visible, near infrared, and short wave infrared part of the spectrum. In view of this, Sentinel-2 multi-spectral data are very promising materials for high-resolution mapping of vegetation (Bontemps et al., 2018; Lang et al., 2019). A series of the VI have been calculated by SAGA GIS. The methodology is based on the formulae embedded in the SAGA GIS summarized in table 2.

\section{RESULTS AND DISCUSSION}

With a VI-based analysis of Sentinel-2 satellite image, the vegetation coverage in Yaoundé, Cameroon, can be reliably assessed and continuously monitored. Validated by histograms, the data shown normal distribution. With the use of remote sensing and SAGA GIS technology, Sentinel-2 enables better visualization of the vegetation coverage. To better analyze the possibilities of Sentinel-2 bands, several colour composites have been visualized.

Figure 1 shows the false colour band combination including infrared, by bands 8-4-2 against the natural colour composite 4, 3, 2 (right). Since the natural combination is based on the visible bands, land cover types are resembling their appearance to the human vision: vegetation is dark green, and urban settlement areas of Yaoundé is bright yellow-white, roads can clearly be seen as white stripes agricultural fields have very light green hues, dry vegetation is brown, urban are steel grey. This band combination is mostly used for urban studies, and not applicable for agricultural studies, as sparsely vegetated areas are hard to distinguish. In contrast, false colour composite shows urban areas as bright cyan, while vegetation is bright red with various hues, which is useful for environmental monitoring. 


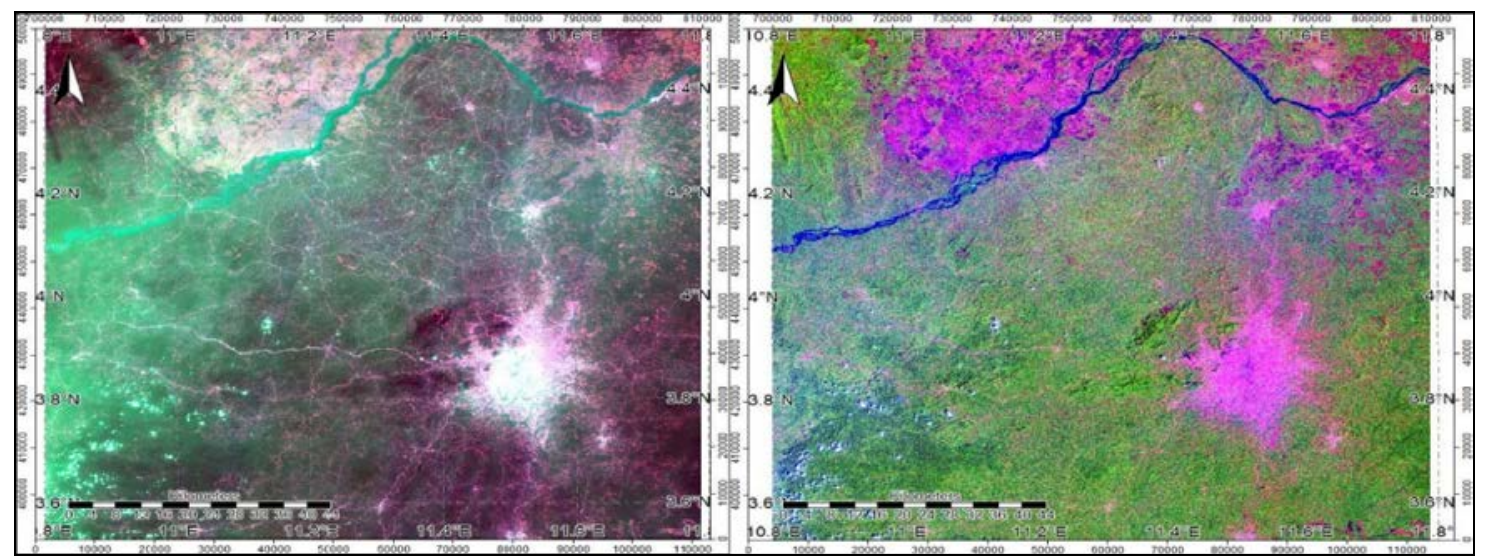

Figure 4: Sentinel-2 bands (B12-1-3) for wetland studies (left); and Sentinel-2 bands (B11-8-2) for agriculture studies (right).

Comparison of Sentinel-2 bands shown in figure 2 presents band combination B12-112, useful for geologic studies due to the rock distinction (Fig. 2, left) against bands B11, B4, B12 which can be used for water detection (Fig. 2, right). The Sentinel-2 bands (B12-11-2), for geologic studies (left). Sentinel-2 bands 11, 4, 12 for water detection (right). Here, water areas are shown in bright green hues and can be separated from the land cove types, while vegetation is shown by burgundy color hues. Wetland and agricultural areas are better visualized with more contrasting colors in figure 4 showing combination of bands 12-1-3 highlighting wetland areas in bright green (left), and bands 11-8-2 for agriculture (right) where urban areas are colored magenta and can be separated from the vegetation areas and forests.

The Sentinel bands can also be visualized as single bands using either monochrome of discrete RGB colour palette. A comparative visualization of a single band 12 in monochrome shaded colours against the discrete 11 colours is shown in figure 5 . The water area in monochrome shaded visualization is clearly visible as white colours, urban areas are black spots. However, the "raw" monochrome cannot be used for image classification due to the lack of information. A comparison of the pixel's frequency distribution by values is presented in figure 6 where the monochrome colour visualization shows the classic bell-shaped histogram with adjusted distribution of grey values over the scaled value range, while the discrete approach of visualization groups pixels into clusters according to their values.

This, however, only concerns the visualization and does not change the values of the raster which varies from 88 to 1490.22 in both cases (X axis in figure 6). Visualized bands of Sentinel-2 B2 and B4 in discrete 11 colours are presented in figure 7 (left and right, respectively). The difference in colour representation illustrates technical characteristics of spectral bands 2 (blue) and 4 (red). As can be seen, the corresponding histogram in band 2 presents finer distribution of pixels with equalized histogram of an image with various levels of pixel values uniformly distributed, while pixels of band 4 are grouped in a coarser approach as colour bar (Fig. 8). 
The NDVI is a good proxy vegetation index showing live healthy green vegetation (Fig. 9, left). The values for the Sentinel-2 image were selected as band 4 for red and band 8 for infra-red. The NDVI shows values in a range 0.2 to 0.67 where the lowest values of pixels close to zero (0.2) correspond to water areas (Sanaga River) followed by the group of low values (0.3-0.4) showing barren areas of rock, as well as sand. As can be noted, there are no negative values of NDVI for this particular scene of Cameron, since the area is located in tropical region with no snow or glacial areas on the image. Low positive values represent shrub and grassland (about 0.4 ), while high values indicate temperate and tropical rainforests (values approaching 0.4 to 0.67 ) with the bright green areas exactly corresponding to the vegetation. The DVI is derived from the simple subtraction of NIR $-\mathrm{R}$, that is, band 8 - band 4, and is now well equalized in term of values (data range from 447,86 to 2010, 36) and data distribution, which can be seen in the histogram comparing to the NDVI (Fig. 10, left and right, respectively). The green areas of vegetation are visually represented by green colours in both cases and separated from "non-vegetation" areas which are coloured by brown hues.

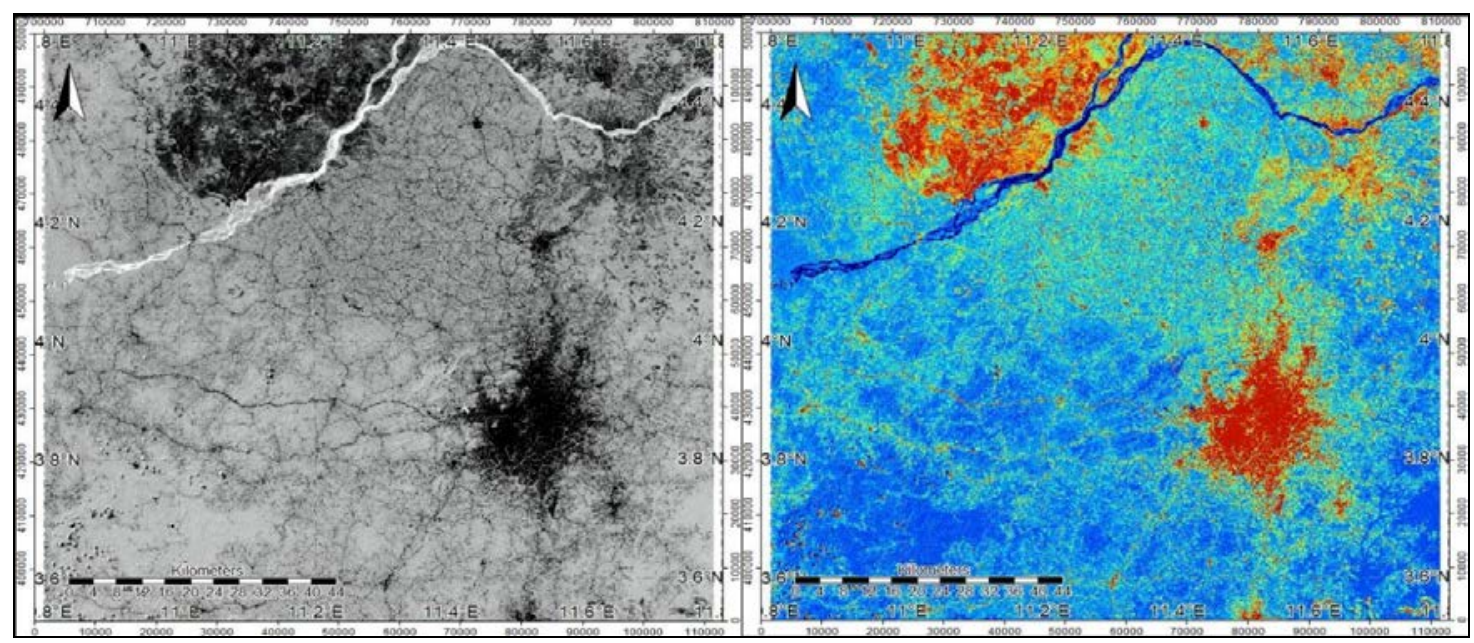

Figure 5: Sentinel Band 12 in monochrome shaded colours (left);

Sentinel-2 single band (B12) in discrete 11 colours (right).

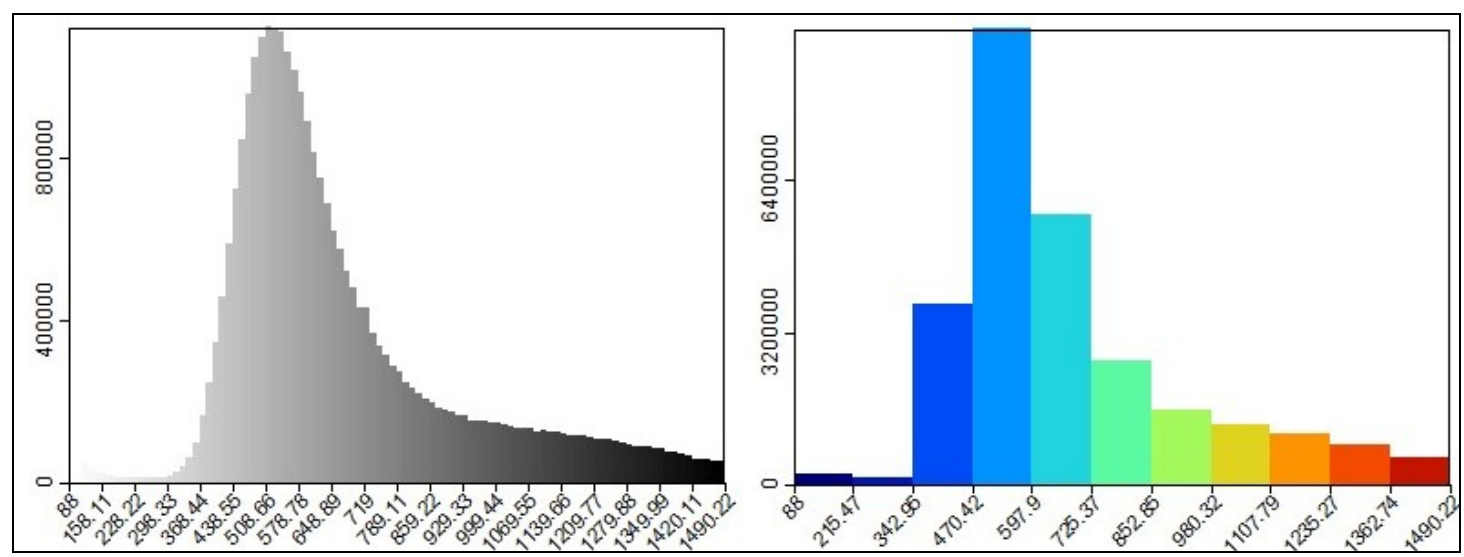

Figure 6: Histograms for the Sentinel Band 12 in monochrome shaded colours (left); Sentinel-2 single band (B12) in discrete 11 colours (right). 
The CTVI (Fig. 11, left) and RVI (Fig. 11, right) indices are also used in remote sensing to measure biomass or vegetative health, and to obtain data on land cover characteristics from multispectral bands of the Sentinel-2. Similar to the NDVI, the RVI is derived by processing two bands of the Sentinel-2: R/NIR, that is, band 4 divided by band 8 for Sentinel-2.

The CTVI has more complex formula according to the equation CTVI $=[(\mathrm{NDVI}+$ $0.5) /$ abs(NDVI +0.5$)] *$ [abs $(\mathrm{NDVI}+0.5)] \wedge 0.5$, which results in the difference of the visualized images. The results of the CTVI calculations (Fig. 11, left) show the dataset range between the 0.83 for the lowest values to 1.09 for the green healthy vegetation. Adding a constant of 0.5 to the initial NDVI values enable to transform low values NDVI into the CTVI. The results of the RVI visualization (Fig. 11, right) show values from 1.4 to 3.9.

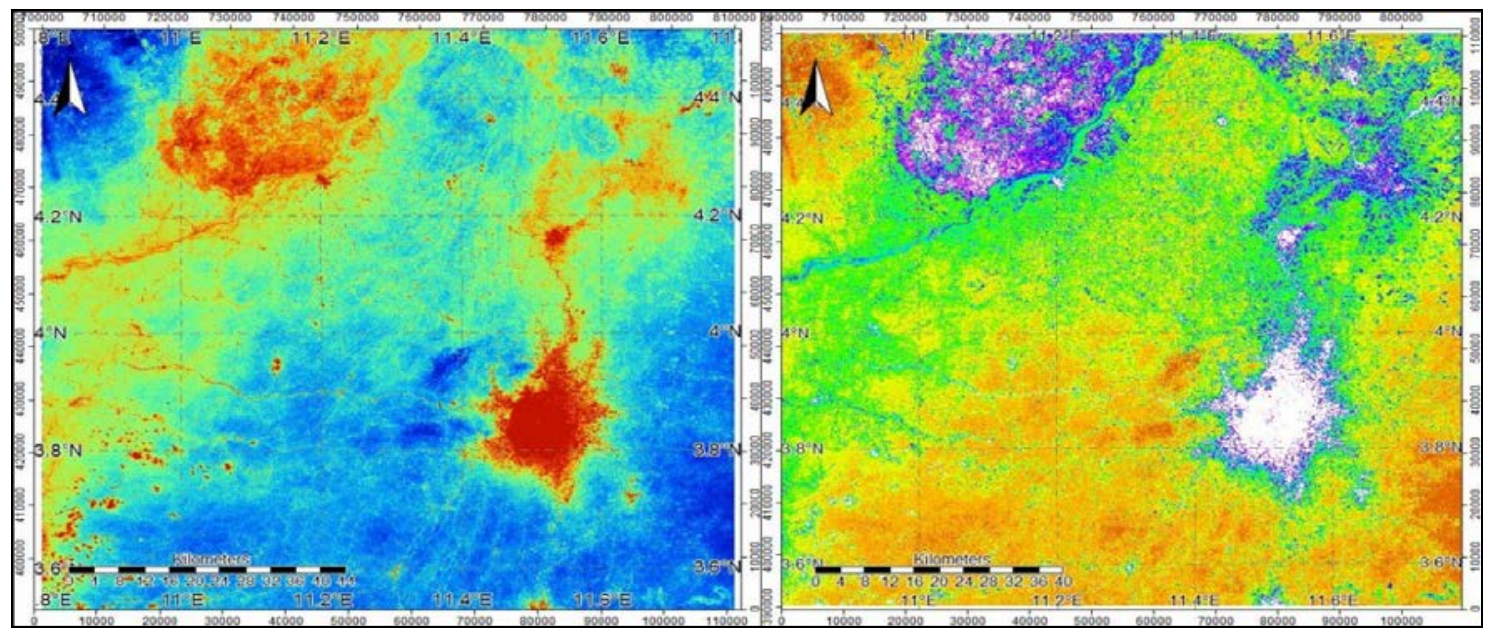

Figure 7: Sentinel-2 B2 in discrete 11 colors (left);

Sentinel-2 B4 in discrete 11 colors (right).

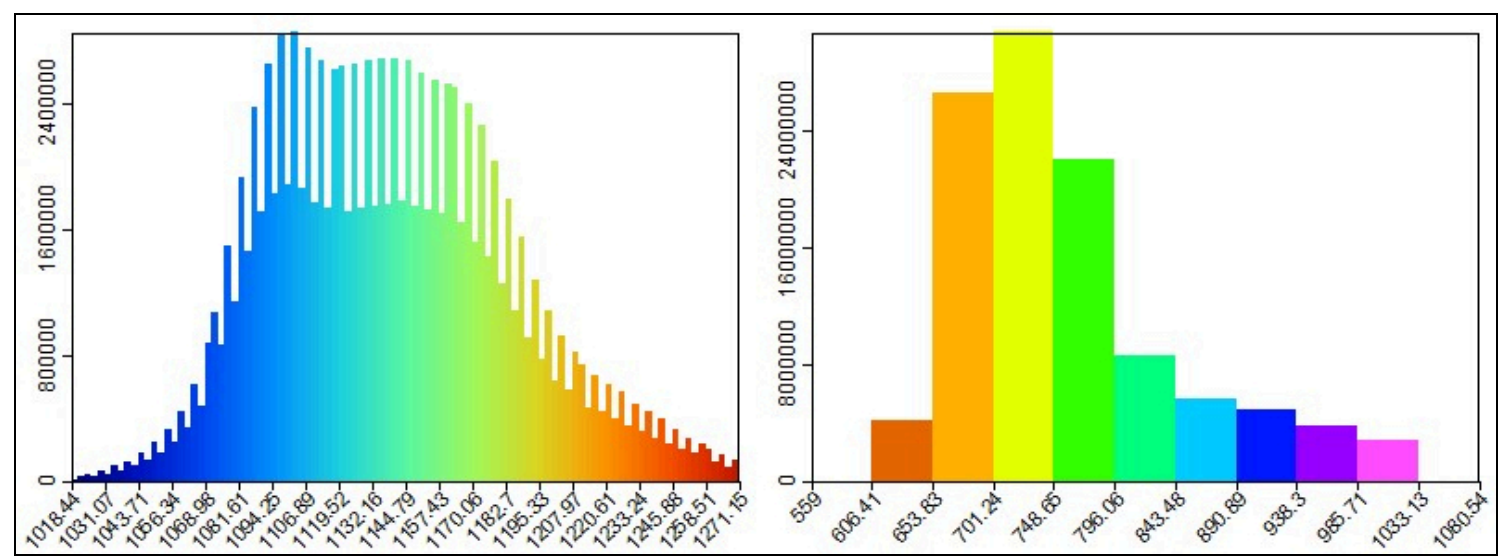

Figure 8: Histograms of pixel distribution of Sentinel-2 band 2 in discrete 11 colours (left); Sentinel-2 band 4 in discrete 11 colours (right). 
As can be seen in a histogram in figure 12, the values of CTVI range from 0.83 to 1.09, while the RVI differs in the range of 1.4 to 3.9, which is explained by the computational algorithm. Examining a colour image of the RVI for the study area of Cameroon, Yaoundé, enables the analyze of the distribution of vegetation, areas of sparse, moderate and dense vegetation coverage presented by green hues, while agricultural areas and urban spaces are shown in shades of brown and beige, and Sanaga River as dark brown. The plant fields have values of $0.87-0.96$, areas with healthy vegetation are $0.98-1$ (a modus of distribution) and the highest vegetation has a range of 1.0 to 1.05 , while areas little vegetation have values of 0.98 to 0.99 . The densest vegetation areas (dark green) with the highest values of index represent the strongest near-infrared reflectance, corresponding to the values in band 8 of Sentinel-2.

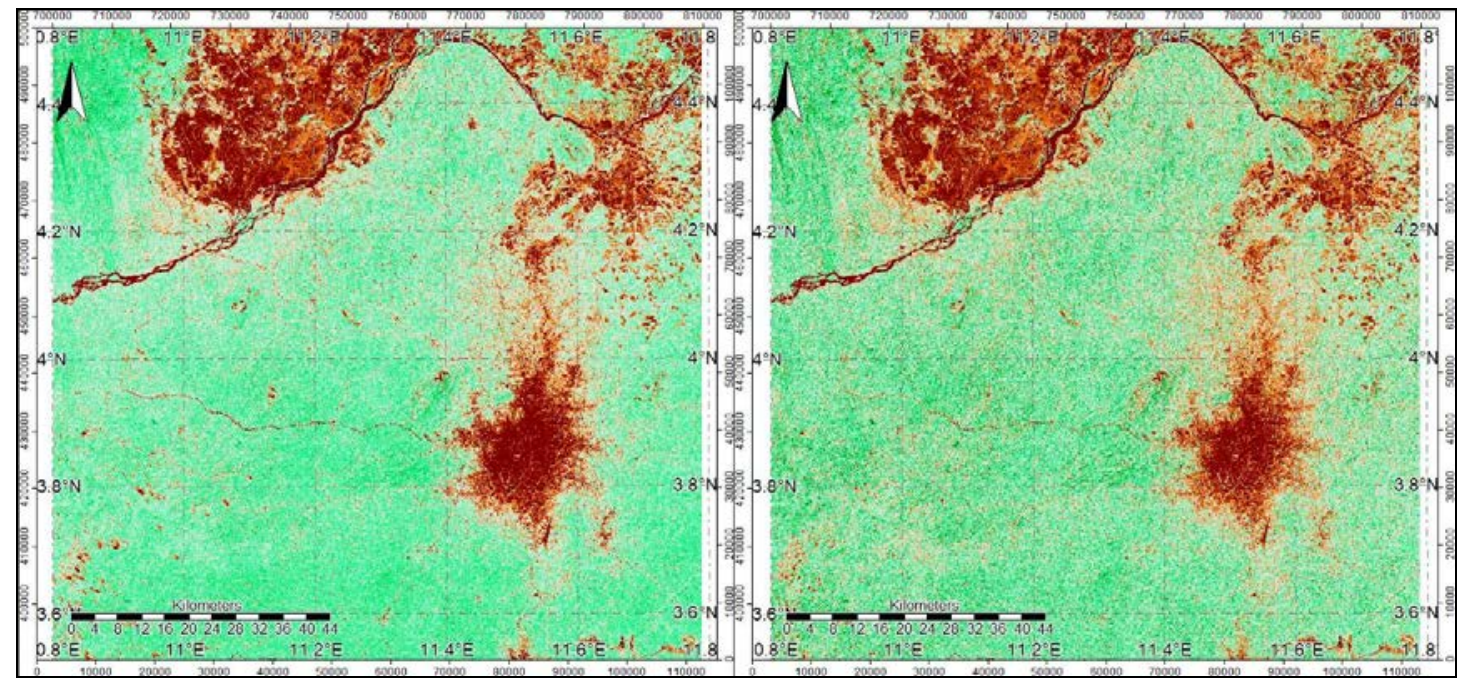

Figure 9: NDVI (left) and DVI (right)

based on Sentinel-2 B8 and B4 bands computation.

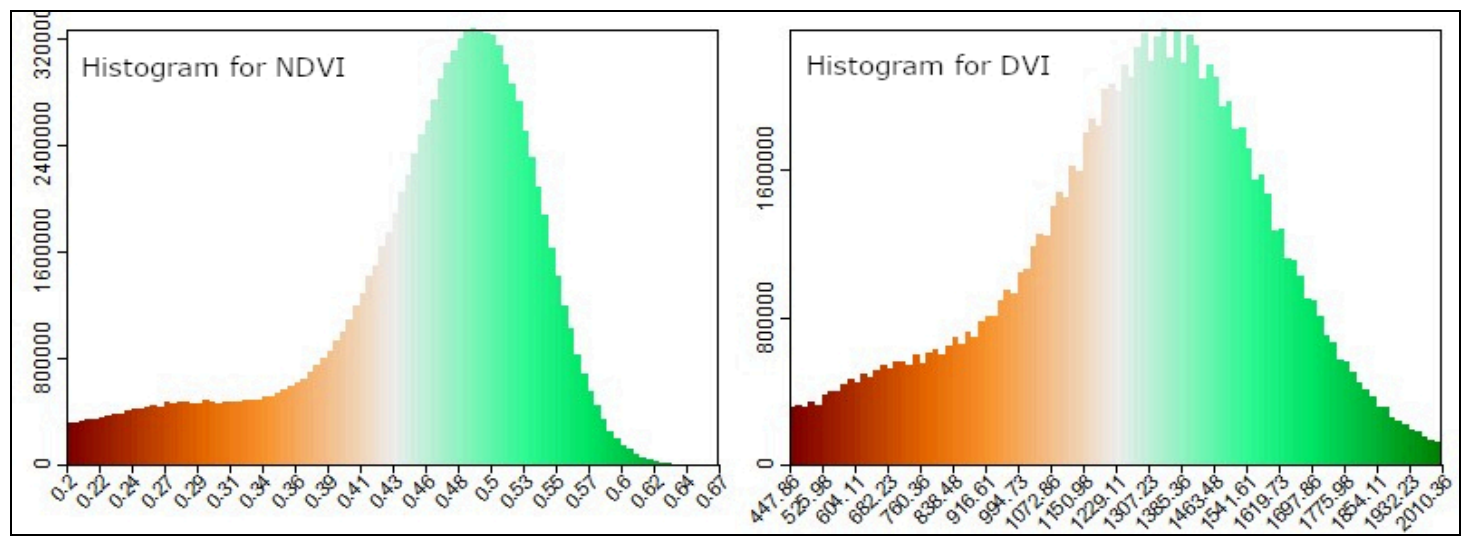

Figure 10: Histograms of pixel distribution of NDVI (left) and DVI (right).

The bright green colors which represent vegetated areas in figure 13 computed by SAVI and TTVI represent the high values of pixels in the NIR where they have a stronger reflectance. This means a higher biomass, which is reflected in values of SAVI and TTVI 
ranging between 0.3 and one for SAVI and 0.83 to 1.09 for TTVI, respectively. This represents regions of dense forests plants in the tropical moist forest with good health, high leaf biomass, dense canopy, and high chlorophyll content in leaves. Conversely, lower SAVI and TTVI values indicate dark beige and brown colors in the urban areas and bare soils. This is as a result of the spectral reflectance, which is higher in the visible band than in the NIR, correlating with regions of water (here: the middle part of the Sanaga River area), mineral rocks, soil, and urban spaces.

The two histograms in figure 14 demonstrate the data distribution for the values of SAVI (left) and TTVI (right) ranging from 0.30 to 0.97 for SAVI and from 0.83 to 1.09 for TTVI, respectively. This represents regions of dense forests plants in the tropical moist forest with good health, high leaf biomass, dense canopy, and high chlorophyll content in leaves. Conversely, lower SAVI and TTVI values indicate a dark beige and brown colours in the urban areas and bare soils. This is as a result of the spectral reflectance, which is higher in the visible band than in the NIR, correlating with regions of water (here: the middle part of the Sanaga River area), mineral rocks, soil, and urban spaces.

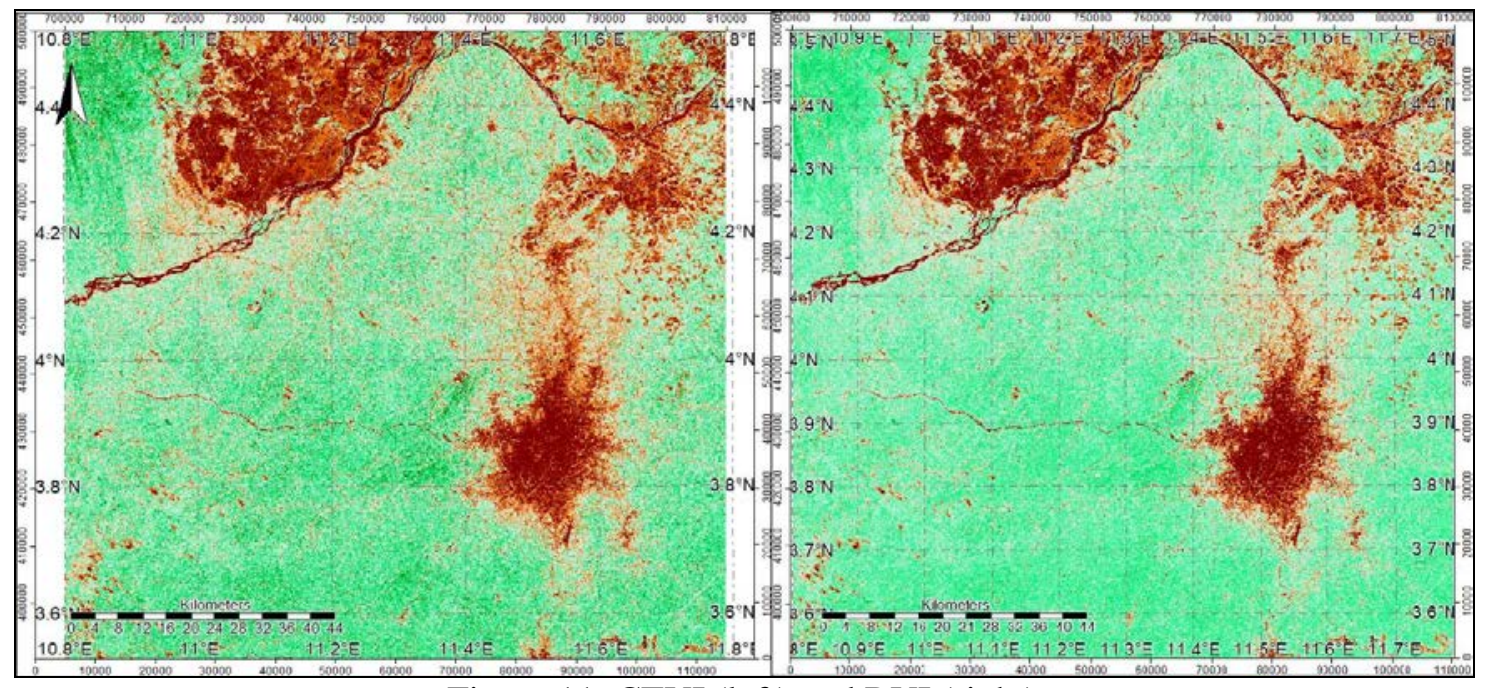

Figure 11: CTVI (left) and RVI (right)

based on Sentinel-2 B8 and B4 bands computation.

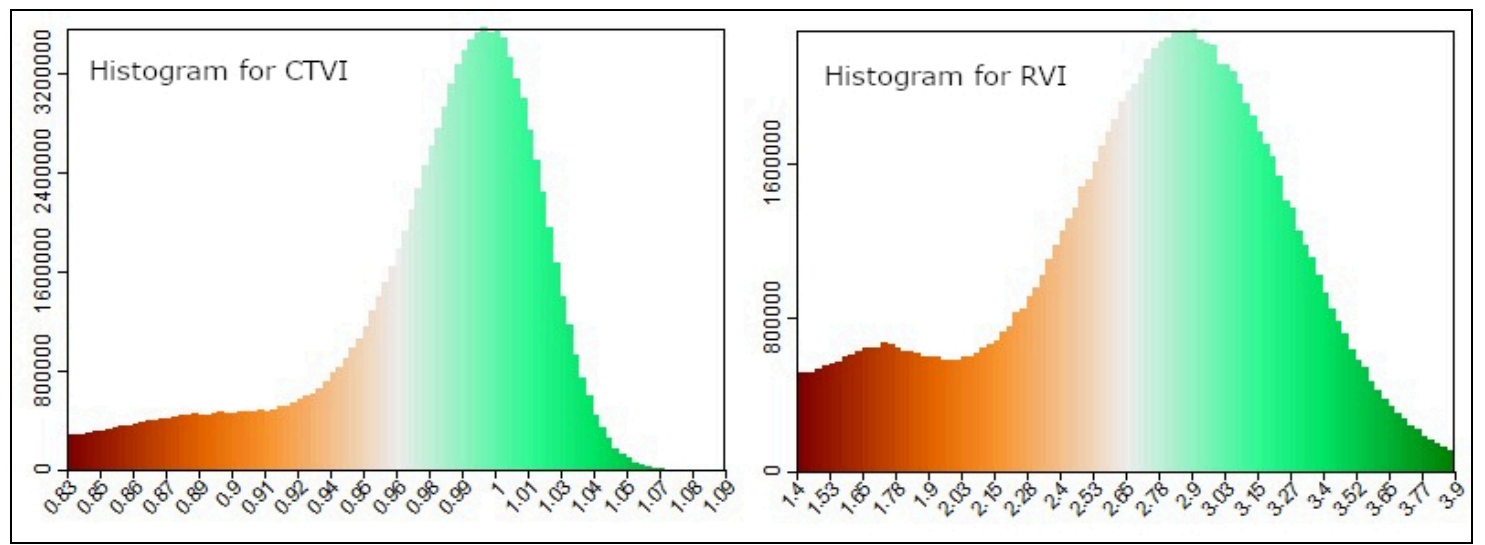

Figure 12: Histograms of pixel distribution of CTVI (left) and RVI (right). 
The agricultural activities can be mapped using the VIs maps for contouring the subsistence farming plantations and separating them from the natural landscapes. The communities of plants in Cameroon include several types of biomes, two types of savanna (moist and dry), and two types of tropical rain forests (evergreen and semi-deciduous). The biodiversity of Cameroon reflects a vast variety of landscapes and geomorphological types: coastlines, mountains, semi-deciduous forests, mixed vegetation, grassland/woody savanna forest deserts, and tropical rainforests to mention a few (Banoho, 2020).

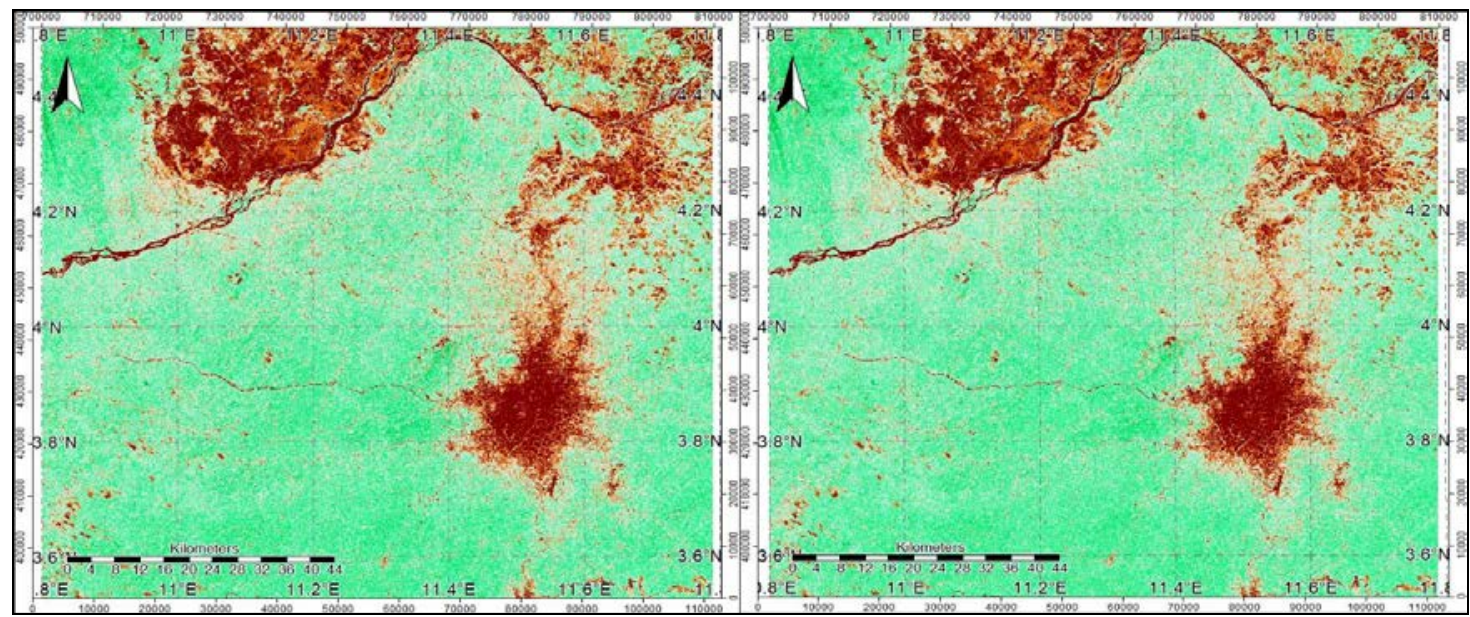

Figure 13: SAVI (left) and TTVI (right)

based on Sentinel-2 B8 and B4 bands computation.

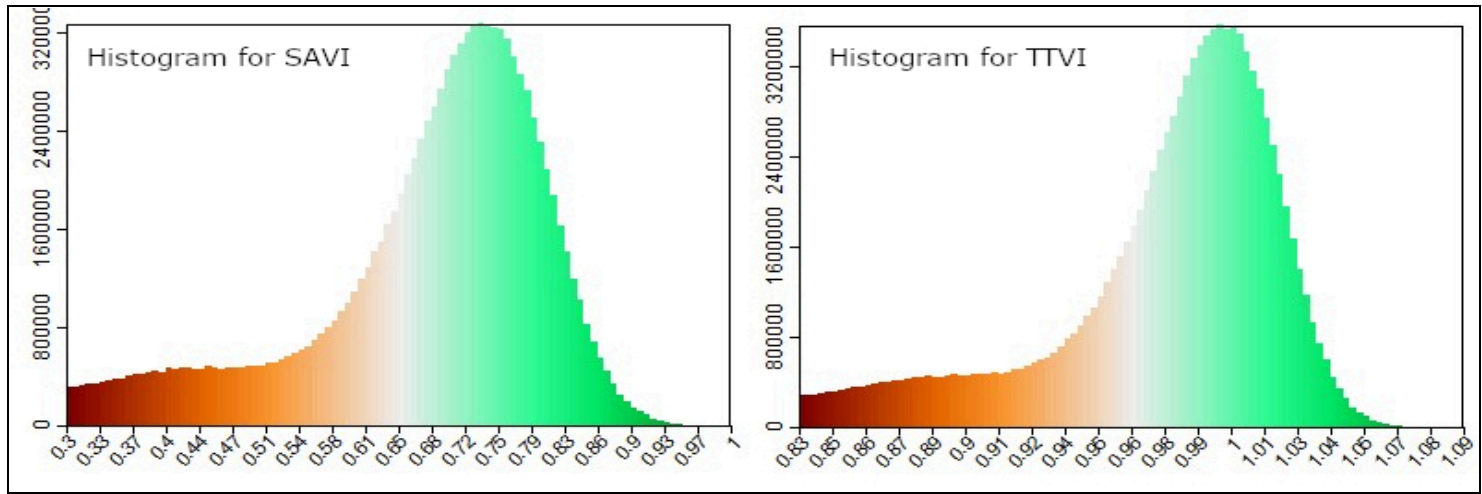

Figure 14: Histograms of pixel distribution of SAVI (left) and TTVI (right).

Vegetation inventory and environmental mapping using remote sensing data and GIS tools are both key approaches in monitoring the vegetation structure, composition, biodiversity, biomass, as well as health, canopy and leaf closure. Rich biodiversity of Cameroon can be illustrated by the following facts: 9,000 plant species, 1,800 genera, and 230 families of vascular plants (Onana, 2011, 2015) including the endangered and endemic species (Sainge, 2016). Besides, tropical forests of Cameroon are precious extents of the Congo Basin and Lower Guinean forest ecosystem which provide a habitat for rare species. In view of this, environmental monitoring of rare ecosystems of Cameroon by GIS algorithms using highresolution remote sensing data is an actual task that may contribute towards the global environmental monitoring. 


\section{CONCLUSIONS}

Addressing the issue of advanced digital mapping for environmental monitoring is implemented not simply by GIS approaches, but by understanding the reasons behind the ecological change and land planning using GIS tools as proposed by Klaučo et al. (2017), as GIS methods are expected to provide additional information on land monitoring. Satellite data provide global coverage that can be used for such cases of the environmental monitoring and mapping ecological variables at high spatial resolutions. Various sensors provide useful geospatial information, for example, the combination of the SRTM and GEBCO, ETOPO1 and ETOPO5 global DEMs is largely used in marine mapping (Lemenkova, 2020a, 2020b). Traganos et al. (2018) used a combination of the Google Earth Engine and Sentinel-2 for a fine-scales bathymetric mapping. Land cover change detection can be derived from well-known Landsat 30-m resolution satellite images (e.g. Lemenkova, 2015a, 2015c) and provide the basis for thematic environmental mapping at multiple spatial and temporal scales.

On the other hand, the application of the machine learning approaches in GIS provide better possibilities for ecological monitoring with the necessary algorithms of data analysis and need to carry various types of cartographic processes (calculation VIs, colour composites, mapping layouts). The advantages of the use of scripting approach in Earth science can improve the GIS procedures so as to increase the quality of the data analysis (McKinney, 2010; Lemenkova, 2019d). The rise of programming technologies applied in Earth sciences makes it possible to quantify data variations through processing techniques by Python and $\mathrm{R}$ (e.g., Clewley et al. 2014; Lawhead, 2019; Lemenkova, 2020c, 2019a, 2019b). Machine learning significantly facilitate mapping techniques, while increasing the speed of plotting, and the precision of the output maps and plots (Schenke and Lemenkova, 2008; Lemenkova, 2019c) over the traditionally GIS based maps, for instance plotted in ArcGIS (e.g. Lemenkova et al., 2012; Suetova et al., 2005a, 2005b) which can be used for machine.

Other approaches, such as statistical analysis in GIS and environmental studies can provide new information about the retrieved datasets on vegetation and ecological ranking through assessment of the landscape metrics, respectively (e.g., Palmer, 2004; Cushman et al. 2008; Klaučo et al. 2014, 2013a, 2013b). These advances are coupled with an application of GIS and methods of geostatistical analysis. As demonstrated in this paper, using SAGA GIS techniques, it is possible to calculate a VIs at $10 \mathrm{~m}$ resolution based on a Sentinel-2 at a regional extent, and to detect urban areas of the city spaces from vegetation.

A series of the slope-based calculated VIs with shown maps and histograms for vegetation of the selected Sentinel-2 satellite scene of Yaoundé surroundings, Cameroon, has been presented for performing SAGA GIS image analysis based on six VI algorithms: 1) NDVI; 2) DVI; 3) SAVI; 4) RVI; 5) TTVI; 6) CTVI. All of the VIs are acceptable for environmental monitoring through SAGA GIS, allowing effective image processing to be easily calculated and visualized in a SAGA GIS GUI menu and applied to Sentinel scenes. Through SAGA GIS, six colour composite bands have been visualized, to illustrate their applicability in various cases: monitoring wetlands and mangroves, agricultural and geologic mapping, and environmental management. Additionally, to illustrate the properties of the Sentinel image, single bands have been visualized using monochrome shaded colours or discrete single band with an enable of bands B2, B4, B12. The study contributed to the environmental studies of Cameroon and demonstration of the satellite image processing for monitoring wetlands and vegetation distribution which can be used for assessment of the ecological resilience to climate change and environmental impacts. 


\section{ACKNOWLEDGEMENTS}

This research was implemented in the framework of the project No. 0144-2019-0011, Schmidt Institute of Physics of the Earth, Russian Academy of Sciences. The author cordially thanks Prof. Dr. Jürgen Böhner for the development of the open source SAGA GIS that enables excellent opportunities of geospatial analysis, cartographic processing and satellite image classification applied for environmental monitoring.

\section{REFERENCES}

1. Amenu B. T. and Mamo G. S., 2018 - Review on wetland ecosystem destruction, International Journal of Scientific Research in Civil Engineering, 2, 2, 5-15.

2. Asangwe C. K., 2006 - The Douala Coastal Lagoon Complex, Cameroon, Environmental Issues, in Administering Marine Spaces: International Issues, Denmark, 20.

3. Asangwe C. K., 2009 - Monitoring wetlands deterioration in the Cameroon coastal lowlands: implications for management, Procedia Earth and Planetary Science, 1, 1, 1010-1015.

4. Asomani-Boateng R., 2019 - Urban wetland planning and management in Ghana: a disappointing implementation, Wetlands, 39, 251-261.

5. Bannari A., Morin D., Bonn F. and Huete A., 1995 - A review of vegetation indices, Remote Sensing Reviews, 13, 95-120.

6. Banoho L. P. R. K., Zapfack L., Weladji R. B., Djomo C. C., Nyako M. C., Nasang J. M., Tagnang M. D. and Mbobda R. B. T., 2020 - Biodiversity and carbon sequestration potential in two types of tropical rainforest, Cameroon, Acta Oecologica, 105, 103562.

7. Baret F. and Guyot G., 1991 - Potential and limitations of vegetation indices for LAI and APAR assessment, Remote Sensing of Environment, 104, 88-95.

8. Beatty W. S., Kesler D. C., Webb E. B., Raedeke A. H., Naylor L. W. and Humburg D. D., 2014 - The role of protected area wetlands in waterfowl habitat conservation: implications for protected area network design, Biological Conservation, 176, 144-152.

9. Brock T. C. M. and van Vierssen W. 1992 - Climatic change and hydrophytes-dominated communities in inland wetland ecosystems, Wetlands Ecology and Management, 2, 37-49.

10. Bosma C., Glenk K. and Novo P., 2017 - How do individuals and groups perceive wetland functioning? Fuzzy mapping of wetland perceptions in Uganda, Land Use Policy, 60, 181-196.

11. Bontemps S., Arias M., Cara C., Dedieu G., Guzzonato E., Hagolle O., Inglada J., Morin D., Rabaute T., Savinaud M., Sepulcre G., Valero S., Defourny P. and Koetz B., 2015 - Sentinel-2 for agriculture: supporting global agriculture monitoring, 2015 IEEE Symposium, 4185-4188.

12. Böhner J., McCloy K. R. and Strobl J., 2006 - SAGA - Analysis and modelling applications, Göttinger Geographische Abhandlungen, 115, 130.

13. Campbell J. B., 2002 - Introduction to remote sensing, Guilford Press, 667.

14. Claverie M., Ju J., Masek J. G., Dungan J. L., Vermote E. F., Roger J.-C., Skakun S. V. and Justice C., 2018 - The Harmonized Landsat and Sentinel-2 surface reflectance dataset, Remote Sensing of Environment, 219, 145-161.

15. Clewley D., Bunting P., Shepherd J., Gillingham S., Flood N., Dymond J., Lucas R., Armston J. and Moghaddam M., 2014 - A Python-Based Open Source System for Geographic ObjectBased Image Analysis Utilizing Raster Attribute Tables, Remote Sensing, 6, 7, 6111-6135.

16. Conrad O., Bechtel B., Bock M., Dietrich H., Fischer E., Gerlitz L., Wehberg J., Wichmann V., and Böhner J., 2015 - System for Automated Geoscientific Analyses (SAGA) v. 2.1.4, Geoscientific Model Development, 8, 1991-2007.

17. Cushman S. A., McGarigal K. and Neel M. C., 2008 - Parsimony in landscape metrics: strength, universality, and consistency, Ecological Indicators, 8, 691-703.

18. Crippen R. E., 1990 - Calculating the vegetation index faster, Remote Sensing of Environment, 34, 71-73.

19. Deering D. W., Rouse J. W., Haas R. H. and Schell J. A., 1975 - Measuring "Forage Production" of Grazing Units From Landsat MSS Data, Proceedings of the 10th International Symposium on Remote Sensing of Environment, 2, 1169-1178. 
20. Fokeng M. R. and Meli M. V., 2015 - Modelling drivers of forest cover change in the Santchou Wildlife Reserve, West Cameroon using remote sensing and land use dynamic degree indexes, Canadian Journal of Tropical Geography, 2, 2, 29-42, http://laurentian.ca/cjtg.

21. Fokeng R. M., Forje W. G., Meli V. M. and Bodzemo B. N., 2020 - Multi-temporal forest cover change detection in the Metchie-Ngoum Protection Forest Reserve, West Region of Cameroon, The Egyptian Journal of Remote Sensing and Space Sciences, 23, 113-124.

22. Fonkou T., Télesphore B. N., Julius B. K., Nguetsop V. F., Lekeufack M., Motue E. S. T., Youga M. K. D. and Mboujda M. F. M., 2017 - Ethnobotanical study on wetland macrophytes of medicinal importance in the Western Highlands of Cameroon, Cameroon Journal of Experimental Biology, 11, 1, 23. DOI: 10.4314/cajeb.v11i1.3.

23. Fritz S., See L., McCallum I., You L., Bun A., Moltchanova E., Duerauer M., Albrecht F., Schill C., Perger C., Havlik P., Mosnier A., Thornton P., Wood-Sichra U., Herrero M., BeckerReshef I., Justice C., Hansen M., Gong P., Abdel Aziz S., Cipriani A., Cumani R., Cecchi G., Conchedda G., Ferreira S., Gomez A., Haffani M., Kayitakire F., Malanding J., Mueller R., Newby T., Nonguierma A., Olusegun A., Ortner S., Rajak D. R., Rocha J., Schepaschenko D., Schepaschenko M., Terekhov A., Tiangwa A., Vancutsem C., Vintrou E., Wenbin W., van der Velde M., Dunwoody A., Kraxner F. and Obersteiner M., 2015 - Mapping global cropland, Global Change Biology, 21, 1980-1992.

24. Gao G., 1996 - NDWI - A normalized difference water index for remote sensing of vegetation liquid water from space, Remote Sensing of Environment, 58, 257-266.

25. Hagolle O., Kadiri M. and Morin D., 2017 - Sentinel-2 Agriculture - Detailed Processing Model for Monthly Synthesis product, Sen2Agri, Université catholique de Louvain, 1-12.

26. Huete A. R. 1988 - A soil-adjusted vegetation index (SAVI), Remote Sensing of Environment, 25, 3, 295-309.

27. Jurgens C., 1997 - The modified normalized difference vegetation index (mNDVI) a new index to determine frost damages in agriculture based on Landsat TM data, International Journal of Remote Sensing, 18, 3583-3594.

28. Klaučo M., Gregorová B., Stankov U., Marković V. and Lemenkova P., 2013a - Determination of ecological significance based on geostatistical assessment: a case study from the Slovak Natura 2000 protected area, Open Geosciences, 5, 1, 28-42.

29. Klaučo M., Gregorová B., Stankov U., Marković V. and Lemenkova P., 2013b - Interpretation of landscape values, typology and quality using methods of spatial metrics for ecological planning, Environmental and Climate Technologies, October 14, 2013, Riga, Latvia, 2.

30. Klaučo M., Gregorová B., Stankov U., Marković V. and Lemenkova P., 2014 - Landscape metrics as indicator for ecological significance: assessment of Sitno Natura 2000 sites, Slovakia, Ecology and Environmental Protection, March 19-20, Minsk, Belarus, 85-90.

31. Klaučo M., Gregorová B., Koleda P., Stankov U., Marković V. and Lemenkova P., 2017 Land planning as a support for sustainable development based on tourism: A case study of Slovak rural region, Environmental Engineering and Management Journal, 2, 1, 6, 449-458.

32. Lambi C. M., Kimengsi J. N., Kometa C. G. and Tata E. S., 2012 - The management and challenges of protected areas and the sustenance of local livelihoods in Cameroon, Environment and Natural Resources Research, 2, 3, 10-18.

33. Lang N., Schindler K. and Wegner J. D., 2019 - Country-wide high-resolution vegetation height mapping with Sentinel-2, Remote Sensing of Environment, 233, 111347.

34. Lawhead J. 2019 - This library reads and writes ESRI shapefiles in pure Python, https://github.com/GeospatialPython/pyshp.

35. Lemenkova P., 2011 - Seagrass mapping and monitoring along the coasts of Crete, Greece, M.Sc. Thesis, University of Twente, Enschede, Netherlands, 158.

36. Lemenkova P., Promper C. and Glade T., 2012 - Economic assessment of landslide risk for the Waidhofen a.d. Ybbs Region, Alpine Foreland, Lower Austria, Protecting Society through Improved Understanding. 11th Symposium on Landslides and the 2nd North American Symposium on Landslides and Engineered Slopes, June 2-8, Banff, Canada, 279-285. 
37. Lemenkova P., 2014 - Detection of vegetation coverage in urban agglomeration of Brussels by NDVI indicator using cognition software and remote sensing measurements, in GIS and remote sensing, November 17-19, 2014, Tsaghkadzor, Armenia, 112-119.

38. Lemenkova P., 2015a - Modelling landscape changes and detecting land cover types by the remote sensing data and ILWIS GIS, in Information Technologies, Problems and Solutions, 265-271.

39. Lemenkova P., 2015b - Analysis of Landsat NDVI time series for detecting degradation of vegetation, in Geoecology and Sustainable Use of Mineral Resources, From Science to Practice, Belgorod, Russia, 11-13.

40. Lemenkova P., 2015c - Technical approach of image segmentation in ENVI GIS to identify thematic clusters for visualization of urban transformations, Conference Proceedings Reality the Sum of Information Technologies, December 14-15, 2015, Kursk, Russia, 100-104.

41. Lemenkova P. 2019a - K-means clustering in R libraries \{cluster\} and ffactoextra\} for grouping oceanographic data, International Journal of Informatics and Applied Mathematics, 2, 1, 1-26.

42. Lemenkova P., 2019b - Testing linear regressions by StatsModel Library of Python for oceanological data interpretation, Aquatic Sciences and Engineering, 34, 51-60.

43. Lemenkova P., 2019c - AWK and GNU octave programming languages integrated with generic mapping tools for geomorphological analysis, GeoScience Engineering, 65, 4, 1-22.

44. Lemenkova P., 2019d - Statistical analysis of the Mariana Trench Geomorphology using R programming language, Geodesy and Cartography, 45, 2, 57-84.

45. Lemenkova P., 2020a - GMT based comparative geomorphological analysis of the Vityaz and Vanuatu Trenches, Fiji Basin, Geodetski List, 74, 1, 19-39.

46. Lemenkova P., 2020b - Variations in the bathymetry and bottom morphology of the Izu-Bonin Trench modelled by GMT, Bulletin of Geography, Physical Geography Series, 18, 1, 41-60.

47. Lemenkova P., 2020c - R Libraries\{dendextend and \{magrittr\} and clustering package scipy.cluster of Python for modelling diagrams of dendrogram trees, Carpathian Journal of Electronic and Computer Engineering, 13, 1, 5-12.

48. McKinney W. 2010 - Data structures for statistical computing in Python, Proceedings of the 9th Python in Science Conference, Austin, TX, USA, 28 June - 3 July 2010, 51-56.

49. Ministry of Environment and Forestry, 1994 - A compendium of official instruments on forest and wildlife management in Cameroon, MINEF, Yaoundé, Cameroon, 185.

50. Ministry of the Environment and Protection of Nature, 2009 - Cameroon fourth national report to the convention on biological diversity, MINEP, Yaoundé, Cameroon, 193.

51. Muam C. A., 1999 - Co-management of forest in Cameroon, The compatibility of government policies with indigenous practices, Published PhD thesis, University of Twente, 197.

52. Ngo-Mbogba M., Yemefack M. and Nyeck B., 2015 - Assessing soil quality under different land cover types within shifting agriculture in South Cameroon, Soil and Tillage Research, $150,124-131$.

53. Nawarathne W. R. M. D. P., Dissanayake S. P. and Ginigaddara, G. A. S. 2020 - Community Perception on Sustainable Utilization of Kaduwela Wetland for Agriculture, Sri Lanka, Sri Lankan Journal of Agriculture and Ecosystems, 2, 1, 78-88.

54. Nowakowski T., 2015 - Arianespace successfully launches Europe's Sentinel-2A Earth observation satellite, Spaceflight Insider.

55. Price R., Kamp-Glass M., Powell D., 1992 - Tissue culture of wetland endangered plant species, HortSience: a publication of the American Society for Horticultural Science, 27, 11, 1166c-1166.

56. Onana J. M., 2011 - The vascular plants of Cameroon, A taxonomic check list with IUCN assessments, Flore du Cameroun 39, IRAD-National Herbarium of Cameroon, Yaounde, 195.

57. Onana J. M., 2015 - The World Flora online 2020 project, will Cameroon come up to the expectation, Rodriguesia, 66, 961-972. 
58. Palmer J. F., 2004 - Using spatial metrics to predict scenic perception in a changing landscape: Dennis, Massachusetts, Landscape and Urban Planning, 69, 201-218.

59. Perry C. Jr. and Lautenschlager L. F., 1984 - Functional equivalence of spectral vegetation indices, Remote Sensing of Environment, 14, 1-3, 169-182.

60. Richardson A. J. and Wiegand C. L. 1977 - Distinguishing vegetation from soil background information, Photogramnetric Engineering and Remote Sensing, 43, 12, 1541-1552.

61. Rouse J. W, Haas R. H., Scheel J. A. and Deering D. W., 1974 - Monitoring vegetation systems in the Great Plains with ERTS, Proceedings, $3^{\text {rd }}$ Earth Resource Technology Satellite (ERTS) Symposium, 1, 48-62.

62. Sainge N. M., 2016 - Patterns of distribution and endemism of plants in the Cameroon Mountains: a case study of protected areas in Cameroon: Rumpi Hills Forest Reserve (RHFR) and the Kimbi Fungom National Park (KFNP), Tropical Plant Exploration Group (TroPEG) Cameroon, 171.

63. Shang R. and Zhu Z., 2019 - Harmonizing Landsat 8 and Sentinel-2: a time-series-based reflectance adjustment approach, Remote Sensing of Environment, 235, 111439.

64. Seiny-Boukar L., Floret C., Moukouri K. H. and Pontanier R., 1992 - Degradation of savanna soils and reduction of water available for the vegetation: the case of northern Cameroon vertisols, Canadian Journal of Soil Science, 72, 481-488.

65. Silatsa F. B. T., Yemefack M., Tabi F. O., Heuvelink G. B. M. and Leenaars J. G. B., 2020 Assessing countrywide soil organic carbon stock using hybrid machine learning modelling and legacy soil data in Cameroon, Geoderma, 367, 114260.

66. Schenke H. W. and Lemenkova P., 2008 - Zur Frage der Meeresboden-Kartographie: Die Nutzung von AutoTrace Digitizer für die Vektorisierung der Bathymetrischen Daten in der Petschora-See, Hydrographische Nachrichten, 81, 16-21.

67. Schneider-Binder, 2020 - Riparian vegetation along the Scroafa Stream and its tributaries (Southern Transylvania) under changing ecological conditions and human intervention, Transylvanian Review of Systematical and Ecological Research - The Wetlands Diversity, 22.2, 31-46.

68. Suetova I. A., Ushakova L. A. and Lemenkova P., 2005a - Geoinformation mapping of the Barents and Pechora Seas, Geography and Natural Resources, 4, 138-142.

69. Suetova I. A., Ushakova L. A. and Lemenkova P., 2005b - Geoecological mapping of the Barents Sea using GIS, in International Cartographic Conference, La Coruna Spain, 5.

70. Takem-Mbi B. M., 2013 - Assessing forest cover change in the Bafut-Ngemba Forest Reserve (BNFR), North West Region of Cameroon using remote sensing and GIS, International Journal of Agricultural Policy and Research, 1, 7, 180-187.

71. Testa S., Soudani K., Boschetti L. and Borgogno Mondino E., 2018 - MODIS-derived EVI, NDVI and WDRVI time series to estimate phenological metrics in French deciduous forests, International Journal of Applied Earth Observation 64, 132-144.

72. Thiam A. K., 1997 - Geographic Information Systems and Remote Sensing, methods for assessing and monitoring land degradation in the Sahel: the case of Southern Mauritania, Ph.D. Thesis, Clark University, Worcester Massachusetts, 490.

73. Traganos D., Poursanidis D., Aggarwal B., Chrysoulakis N. and Reinartz P., 2018 - Estimating Satellite-Derived Bathymetry (SDB) with the Google Earth and Sentinel-2, Remote Sensing, 10, 6, 859.

74. Tsozue D., Nghonda J. P. and Mekem D. L., 2015 - Impact of land management system on crop yields and soil fertility in Cameroon, Solid Earth, 6, 1087-1101.

75. Xu H., 2006 - Modification of normalised difference water index to enhance open water features in remotely sensed imagery, International Journal of Remote Sensing, 27, 3025-3033.

76. Wanzie C. S., 2003 - Wetland conservation and development in the Sahel of Cameroon, in Jamin J. Y., Seiny Boukar L. and Floret C. (eds), Savanes africaines: des espaces en mutation, des acteurs face à de nouveaux défis, Actes du colloque, mai 2002, Garoua, Cameroun, Prasac, N’Djamena, Tchad - Cirad, Montpellier, France, 6. 